\title{
Linking Status with Soft Power: Call for a Joint Research Agenda
}

\author{
Eleonora Tafuro Ambrosetti \\ Middle East Technical University
}

\section{Review article of:}

T. V. Paul, Deborah Welch Larson, and William C. Wohlforth, eds., Status in World Politics (New York: Cambridge University Press, 2014, 324 pp., USD 29.33, paperback).

\section{Introduction}

The importance of non-Western regions for international politics and economy has been growing steadily in the last few decades. In particular, countries like Brazil, Russia, India, China and South Africa - popularly known as BRICS - and other so-called "middle powers" such as Turkey have been forming increasingly relevant poles of power, in a way that seems to suggest that the "unipolar moment" and US hegemony are, at this point, largely gone. ${ }^{1}$ What is the nature of these processes and their consequences for global governance and International Relations (IR)? More specifically, in what ways do rising powers' claims challenge - or even destabilise - the current world order? And is their rise necessarily a turbulent process?

The authors and editors of Status in World Politics believe that a focus on the concept of status can help answer these complex questions. They are not alone in considering status concerns as a stepping stone in explaining the behaviour of emerging powers. Status has been historically important and noted as an explanatory factor in several instances; the struggle of Mussolini's fascist regime to establish overseas colonies is a case in point. Italy, which achieved unity only in 1861, strived hard to obtain the status of a colonial empire, considered a conditio sine qua non, to be on a par with other European great powers. In IR theory, the concept of status pervades the writings of English School scholars such as Hedley Bull and Adam Watson, who conceptualised the international system in terms of social order and status hierarchies. ${ }^{2}$ English School scholars also acknowledge the intersubjective and social nature of status, which does not solely result from a state's material capabilities but is rather conferred by the recognition of others. The editors of the book note that "the past decade has witnessed an outpouring of new multidisciplinary research on status in international politics." 3

\footnotetext{
Eleonora Tafuro Ambrosetti, Marie Curie Early Stage Researcher,* METU, Ankara. Email: eleonora.tafuro@gmail.com.

*This research has received funding from the European Union's Seventh Framework Programme for research, technological development and demonstration under grant agreement no 607133.

1 ...if US hegemony ever existed. For an interesting and fresh take on the (in)existence and unnecessity of US hegemony, see Simon Reich and Richard Ned Lebow, "Influence and Hegemony: Shifting Patterns of Material and Social Power in World Politics," All Azimuth 6, no. 1 (2017):17-47.

2 Hedley Bull and Adam Watson, The Expansion of International Society (Oxford: Oxford University Press, 1984).

3 T.V. Paul, Deborah Welch Larson, and William C Wohlforth, "Introduction," in Status in World Politics (New York:
} 
The literature discussing the link between emerging powers and status concerns has also flourished. In light of the BRICS' economic boom, several authors have investigated the status concern of these countries. Yong Deng and Fei-ling Wang, for instance, argue that the "Chinese Communist Party regime's security, economic development and quest for great power status are the central concerns driving Chinese foreign policy," and that Chinese elites are clearly dissatisfied with the current status enjoyed by their state. ${ }^{4}$ Deng claims that, while China's status concerns are "palpable," there is actually some confusion around China's status motivations in Chinese writings as well as in English-language literature. ${ }^{5}$ He believes that China considers status advancement as pivotal to its national security interests and that status can only be advanced on materialistic and socio-political fronts. ${ }^{6}$ In exploring status conflicts between Russia and the West, Tuomas Forsberg claims ${ }^{7}$ that what really matters is not objective status but perceptions thereof, and there seems to be a gap in how Russia and the West perceive status in general. This gap can be better understood, in Forsberg's opinion, by putting perceptions and emotions at the centre of the analysis. Paulo Roberto de Almeida and Miguel Diaz affirm that "Brazil has long believed that it was destined for greatness" due to the country's geographical size, its natural beauty and resources, and its heritage as part of Portugal's great seafaring empire. However, despite Brazil's proclaimed readiness to assume its "rightful place" among leading global stakeholders, the great powers have repeatedly rebuffed the country's many recent requests to join their ranks. ${ }^{8}$ Focusing on Brazil, India, and China (BIC), Miles Kahler discusses the way in which these three countries interact with the great powers in their quest to eliminate their developing country status given their economic successes. According to the author, the BICs do not appear to radically challenge the status quo in global governance, but their proposals for change in the status hierarchy fall within the scope of reforming the existing order. ${ }^{9}$

Hence, in light of this renewed academic interest in the topic, the editors of Status in World Politics stress that they make three main "novel analytic departures." ${ }^{10}$ Firstly, they claim to go beyond the great-power subsystem and the issue of systemic war. While this claim is certainly true, it is hardly novel; the focus on rising powers and their status concerns has been encouraging an increasing number of researchers over the last years, as the examples above suggest. Secondly, the book brings together scholars utilizing different approaches, ranging from realism and rationalism to political psychology and critical constructivism. This diversity in terms of analytical and epistemological approaches is indeed present, and

\footnotetext{
Cambridge University Press 2014), 5. Many of the authors contributing in the book previously published relevant studies about status. See for instance: Deborah Welch Larson and Alexei Shevchenko, "Status Seekers: Chinese and Russian Responses to U.S. Primacy," International Security 34, no. 4 (2010): 63-95; Renato Corbetta, Thomas J. Volgy, Ryan G. Baird, and Keith A Grant, "Status and the Future of International Politics," in Major Powers and the Quest for Status in International Politics: Global and Regional Perspectives, edited by Thomas J. Volgy, Renato Corbetta, Keith A. Grant, and Ryan G Baird (New York: Palgrave Macmillan US), 203-24; Deborah Welch Larson and Alexei Shevchenko, "Russia Says No: Power, Status, and Emotions in Foreign Policy," Communist and Post-Communist Studies 47, no. 3 (2014): 269-79.

4 Yong Deng, Fei-ling Wang, China Rising: Power and Motivation in Chinese Foreign Policy (Lanham: Rowman \& Littlefield, 2005), 1 .

Yong Deng, "Better than Power: 'International Status' in Chinese Foreign Policy," in Deng and Wang, China Rising, 52. Deng, "Better Than Power," 58.

Tuomas Forsberg, "Status Conflicts between Russia and the West: Perceptions and Emotional Biases," Communist and PostCommunist Studies 47, no. 3 (2014): 323-31.

Paulo Roberto de Almeida and Miguel Diaz, "Brazil's Candidacy for Major Power Status," in Powers and Principles: International Leadership in a Shrinking World, ed. Michael Schiffer and David Shorr (Lanham, MD: Lexington, 2009), 225.

Miles Kahler, "Rising Powers and Global Governance: Negotiating Change in A Resilient Status Quo," International Affairs 89, no. 3 (2013): 711-29, 726

${ }^{10}$ Larson, Wohlforth, and Paul, "Introduction," 6.
} 
represents one of the main strengths of the book. And finally, the editors underscore how the book engages with scholarly voices that have reservations on the critical importance of status as an analytical tool. This is also an interesting feature of the book, which enhances the debate among the authors.

In this review article, I reflect upon the book's main strengths and weaknesses along three lines: after summarizing the authors' main findings, a) I explore why a deeper reflection on the identity of the rising powers is central to the analysis of their status expectations and concerns (Section 3). b) I explore the conceptual link between status in the twenty-first century and the concept of soft power (Section 4), which the authors overlook. And c) I reiterate the main points and make a case for linking status and soft-power research programmes (Conclusion).

\section{Status Matters...}

To affirm that status matters is easy, but it is far more difficult to operationalise it and grasp its numerous dimensions and subtle nuances. Building on Durkheim and Weber's classical definition of status as a hierarchy of social groups ranked in terms of societal values, the authors define status as "collective beliefs about a given state's ranking on valued attributes (wealth, coercive capabilities, culture, demographic position, socio-political organization, and diplomatic clout)." $" 11$ They also note that status in an organisation or an informal hierarchy is collective (rather than individual), subjective (i.e. it depends on others' perceptions), and relative (it involves comparison with others). The authors then identify four key issues around which the analysis of status revolves. These are a) the politics of admission into the greatpower club, b) status signalling and perception, c) the role of institutions, and d) a critical debate on status as opposed to structure and authority. Their key findings, usefully presented in the Introduction, are also listed according to each of those four issues.

The first issue, that is, how to accommodate new powers' claims to great-power status, is possibly one of the most pressing matters in IR, and has been keeping IR scholars busy for decades. Status recognition and status markers are key concepts that have evolved greatly throughout the centuries. Status markers, in particular, are very much time- and culturebound. For instance, Neumann briefly traces their evolution in Chapter 4, reporting that the main status markers in the eighteenth and nineteenth centuries were dynastic marriages and membership in the European Concert, respectively; today, status markers include a permanent seat in the United Nations Security Council (UNSC) or membership in the G8. Gaining status recognition today might also be a very different process that it used to be in the previous centuries. Larson and Shevchenko argue in Chapter 1 that in the current world, where majorpower war is unthinkable, rising powers such as India, Brazil, and Turkey are not gaining status recognition through military achievements but through their rapid economic growth, active role in regional organisations, global diplomacy and foreign aid programs, and by offering a developmental example for the region. This is not to say that material capabilities no longer matter. However, predictably, economic or military power alone will not suffice to achieve membership in the great-power club. ${ }^{12}$

When it comes to the second major issue - status signalling - the discussion focuses around the rhetoric, diplomatic activity, and acquisition of status symbols by the rising powers, on the one hand, and the old powers' abilities to accurately grasp those new powers' signals, on

\footnotetext{
11 Paul, Larson, and Wohlforth, "Introduction," 7.

12 See the discussion on the relation between status and soft power in the fourth section.
} 
the other. As for status signalling, both material (the enhancement of military capabilities, for instance) and immaterial factors (such as Turkey's bid to act as a regional mediator in light of its Ottoman Empire legacy) matter. However, different audiences can interpret the same signals differently. Just as in the case of the security dilemma, misperception and miscommunication about status signalling can drive states into a "status dilemma."13 This notion, introduced by Wohlforth in Chapter 5, explores the uncertainty created by the misperception of a state's status aspirations, which, in turn, might lead to conflict between states that would otherwise have no serious conflict over their relative status. Wohlforth uses status dilemma to explain crucial historical instances such as the Crimean War or the Cold War. In the Cold War case, the author claims that while the two superpowers did enjoy a special status above the rest, they actually were not equal, as the US ranked above the Soviet Union. To achieve formal superpower parity, the USSR started a series of competitive rather than defensive securitymaximising expansionist moves, which sparked more competitiveness. In fact,

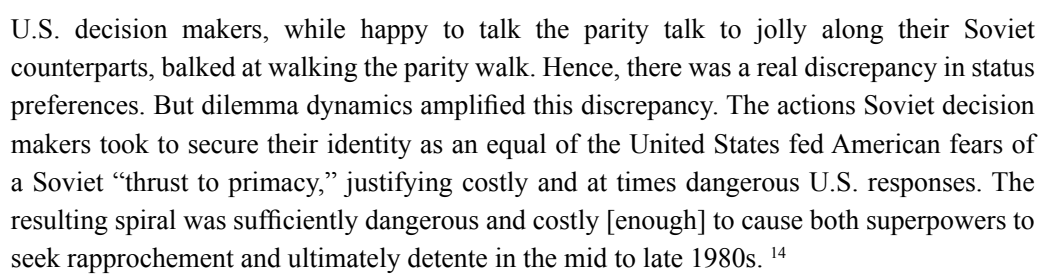

Finally, the tendency for states to boost their strengths while minimizing their weaknesses, makes signalling more complicated. Larson and Shevchenko ${ }^{15}$ point out that countries with limited military power such as Brazil pursue a "social creativity strategy to draw attention to their distinctive strengths."

The importance of international institutions for status is the third issue. The findings expectedly underline the critical interaction between status and institutions, the latter of which have a highly symbolic value as status-shapers. Paul and Shankar argue in Chapter 7 that leadership positions in international institutions or membership in elite clubs can make status-seeking by current rising powers less conflictual now compared to the past. They quote as an example the formation of the more inclusive Group of 20 (G20), which largely replaced the G8 as the premier forum for managing the global economy. Today there are plenty of examples of more inclusive organizations for rising powers to join, such as the BRICS and Shanghai Cooperation Organization - although their actual impact on global governance is debatable. ${ }^{16}$

Several chapters of Status in World Politics also confirm the view that status is an inherently scarce resource and that the process of status-seeking may generate international conflict, especially when rising powers perceive that the current order (the institutions and structures created by the established powers) constrains their rise (as Thompson suggests in

\footnotetext{
13 William C. Wohlforth, "Status Dilemmas and Interstate Conflict" in Paul, Larson, and Wohlforth,, Status in World Politics, 115 .

14 Wohlforth, "Status Dilemmas and Interstate Conflict," 138-9.

15 Deborah Welch Larson and Alexei Shevchenko, "Managing Rising Powers: The Role of Status Concerns," in Paul, Larson, and Wohlforth, Status in World Politics, 35.

16 For instance, while the increasing importance of the BRICS countries in the world economy is a fact (currently mainly due to China and India), the actual significance of the BRICS organisation for global governance is less obvious. Russia has tried to move the organisation from a purely economic and rather unstructured group to a more political one. However, these efforts have not yet met with concrete results in terms of decisional power in the global arena.
} 
Chapter 9). Yet, these chapters also highlight that conflict need not to be the only outcome generated by new powers' status-seeking behaviours; their desire for enhanced status can be a force for good, such as in shaping a more proactive foreign policy, incentivising their participation in regional conflict resolution, or promoting free trade areas.

The fourth and final section of the book includes two authors, David A. Lake and William R. Thompson, who engage critically with the other authors of the book. While Lake contends that many of the most important effects attributed to status actually spring from contests over authority, Thompson makes a distinction between status with a little 's' (concerns about a state's ranking) versus status with a big ' $S$ ' (a state's position in the international system), suggesting that only the latter matters, as it can become a driver of conflict. The conclusion by Clunan puts all these views together, providing an overview of the state of research on status. As the title of the chapter ("Why Status Matters in World Politics") makes clear, the author also makes a strong case for the necessity and originality of the book's research programme on status.

\section{3. ....and So Does the Identity of Rising Powers}

Status in World Politic's geographical focus is diverse. Many countries from very different regions are analyzed, however, they all share one feature: they are rising powers. The starting point is indeed the assumption that rising powers seek status, and that this process is worth a careful analysis for its possible implications for world order and global governance, especially with regard to the nature (violent or pacific) of their efforts to achieve their status objectives. Yet, a fundamental question seems to remain unanswered: what do we mean exactly by "rising powers"? Larson and Shevchenko offer a brief and unsatisfactory definition of "rising powers" (which they also call "emerging powers" or "new powers"): "New powers such as Brazil, India, China, and Turkey have distinctive national interests and may not be amenable to accepting arrangements drafted by the established powers." ${ }^{17}$ This definition points at two strategic factors: the heterogeneity of rising powers and their national interests, and the possible contestational nature of their claims. However, a more expanded definition is needed in order to explain why and how status matters.

In almost all chapters of the book, the term rising power is used interchangeably with emerging powers. This is a broad and somewhat vague category, indicating countries whose economy and/or political influence are on the rise, compared to established powers and to underdeveloped countries. According to Stuenkel, ${ }^{18}$ to be described as an emerging power, a country usually needs to be a) large (both geographically and population-wise), b) poorer on a per-capita basis than industrialised countries, and c) following a escalating pattern that inspires optimism in the country's future outlook in a way that those countries are incentivised to depict themselves as "rising." However, there is no clear definition of the indicators signalling when a country ceases emerging and becomes a major power or, alternatively, when it fails to emerge. Is it possible to rely solely upon economic measurements? While GDP per capita is widely used as a satisfactory measure of growth, taking into account redistribution, it falls short of including other relevant factors of human progress such as social cohesion and the environment. Recently, the Social Progress Index (SPI) or the Genuine Progress Indicator (GPI) have started replacing GDP per capita in some cases, showing that countries

\footnotetext{
17 Larson and Shevchenko, "Managing Rising Powers," 33

18 Oliver Stuenkel, Post-Western World: How Emerging Powers Are Remaking Global Order (Cambridge: Polity Press, 2016).
} 
can experience vastly different levels of social progress even if they have similar levels of GDP per capita. For instance, when it comes to social progress, Ghana (58.29) outperforms Nigeria (43.31) even though it has a lower GDP $-\$ 3,864$ versus $\$ 5,423 .{ }^{19}$ A wider use of these new and more comprehensive indexes would be useful to determine the progress or decline of rising powers.

Emerging powers have different needs and expectations compared to today's established powers. Climate change is a typical example of a policy field where emerging and established powers' claims clash. While rich European powers lead the way to cutting emissions, things look different for emerging powers such as China or India, where millions of people are making a transition from poverty into the middle class, a development that causes a radical increase in per capita emissions. Therefore, emerging powers generally associate cutting emissions with curtailing their own development. And emerging powers largely differ among themselves, too. It is true that the majority of the book's chapters use concrete states as examples; some, like Neumann's chapter on Russia, even focus specifically on the peculiarities of a particular rising power's approach. Yet, a deeper reflection on how particular identities in this varied group impact their general status concerns is needed.

Differentiating between emerging and re-emerging power is key when assessing the 'expectations versus reality' gap. Several countries usually labelled as "emerging" actually do not feel that the word does justice to their history or to their previous role in international relations. Countries like China, Russia, and India often prefer to describe themselves as "reemerging" powers in light of their previous glories. This is not only a matter of labels or national pride. Volgy and colleagues argue that some states are either over- or underachievers in that they receive more or less status recognition than their material capabilities would warrant. ${ }^{20}$ Status overachievers such as Russia, Britain, or France benefit from a "halo effect": thanks to their long history of being great powers, they continue to enjoy major power status, even after losing critical capabilities, and hence continue to enjoy the ability to play on the global stage. Although Volgy et al. acknowledge that a country's former glories can indeed affect its self-image as well as other countries' perceptions, neither they nor the other authors assess the specific impact of being 'genuinely new powers' on a country's status claims. These powers have different expectations and claims about what their role on the global stage should be. In a recent article, Freedman argues that this difference matters greatly when it comes to status preferences and status signalling. He claims that many IR scholars concerned with explaining status-seeking behaviour (this goes for most authors in the book, too) draw heavily from social comparison theory and the assumption that both individuals and states "judge their worth, and accordingly derive self-esteem, through social comparisons with others." ${ }^{21}$ Freedman, on the other hand, draws upon psychology to claim that individuals and states self-evaluate their performance using both social and temporal forms of comparison, that is, they evaluate how they have improved or declined over time, and in turn, the way they self-evaluate themselves affects their status-signalling behaviour. In my opinion, this difference is crucial and helps explain the different status claim between, for instance, Brazil and Russia.

\footnotetext{
19 Michael Green, "Why we shouldn't judge a country by its GDP,” TED Ideas, April 22, 2015, accessed April 10, 2017, http:// ideas.ted.com/why-we-shouldnt-judge-a-country-by-its-gdp/.

${ }^{20}$ Thomas J. Volgy, Renato Corbetta, J. Patrick Rhamey, Jr., Ryan G. Baird, and Keith A. Grant, "Status Considerations in International Politics and the Rise of Regional Powers," in Paul, Larson, and Wohlforth, Status in World Politics.

21 Joshua Freedman, "Status Insecurity and Temporality in World Politics," European Journal of International Relations 22, no. 4 (2016): 797-822.
} 


\section{Status and Soft Power}

The salience of norms for both status attainment and maintenance is widely acknowledged throughout Status in World Politics. Clunan affirms that evolving normative understandings and social institutions impact a country's status regardless of changes in its material capabilities. A country, she claims, "may even fall out of the status in-group as new normative standards arise that challenge its fitness." ${ }^{22}$ Larson, Paul, and Wohlforth underscore, perhaps not without some liberal bias, that "the importance of meeting prevailing normative standards...heightens uncertainty about whether Russia, China, and other nonliberal states will attain the recognition that they seek." ${ }^{23}$ But what happens when rising powers engage in normative contestation processes in order to enhance their status? In what ways do these countries contest the existing normative order to promote alternative ones?

These questions remain largely unanswered throughout the book, despite their relevance to status research. In this regard, a more active engagement with the concept of soft power - one of the most famous and highly debated IR concepts, and a possibly useful analytical tool to address these questions - could open interesting research avenues for both status and soft-power researchers. The concept of soft power - coined by Harvard Professor Joseph Nye - has been present for more than 20 years now, used by scholars and especially practitioners. Defined as the ability to achieve political ends through attraction and preference-shaping, ${ }^{24}$ the concept has been widely criticised for presenting researchers with several conceptual and analytical challenges (some of them, such as the measurability of such a volatile concept, are shared by status, too). Recently, there have been attempts to fine-tune and improve the concept, and to adapt to the study of rising powers. These developments link nicely with status research. For instance, in a recent publication, I suggest re-defining soft power in a way that transcends its usual identification with liberal democracy, hence also fitting nonliberal and non-Western rising powers. Building on Gramscian theory, I argue that soft power is the "ability of a state or a group within the state to influence discourses in such a way that certain policies, worldviews and narratives are framed as 'common sense,' paving the way to the establishment of power relations." ${ }^{25}$ The most recent soft-power literature focuses on China and Russia, for these are the countries that, whether for a strategic purpose or to contest Western normative hegemony (or both), are conveying stronger alternative normative claims through their soft-power activities. Examples of these studies abound; ${ }^{26}$ to quote just one, Chaka Ferguson argues that Chinese and Russian strategists have incorporated "soft" or "normative" power assets into their foreign policy, and that their alternative norms, such as

\footnotetext{
22 Anne L. Clunan, "Why Status Matters in World Politics," in Paul, Larson, and Wohlforth, Status in World Politics, 284.

23 Paul, Larson, and Wohlforth, "Introduction," 21.

24 Joseph Nye, The Future of Power (New York: Public Affairs, 2011).

25 Eleonora Tafuro Ambrosetti, "Building a Sphere of Influence in Their Neighbourhood. The Soft Power of Turkey and Russia” (PRIMO Working Papers Series 5, January 2017, Hamburg), 17.

26 On Russia see, Fiona Hill, "Moscow Discovers Soft Power," Current History 105, no. 693 (2006): 341-47; Nico Popescu, "Russia's Soft Power Ambitions," CEPS Policy Briefs 115 (2006): 1-3; Valentina Feklyunina, "Soft Power and Identity: Russia, Ukraine and the "Russian world(s)," European Journal of International Relations 22, no. 4 (2015): 1-24; Marlene Laurelle, "The Russian World," International Affairs 55, no. 1 (2015): 116-22; Yelena Osipova, "Russification of Soft Power: Transformation of a Concept," Exchange: The Journal of Public Diplomacy 5, no. 1 (2014): 56-77. On China see, Bates Gill and Yanzhong Huang, "Sources and Limits of Chinese 'Soft Power'," Survival 48, no. 2 (2006); Kalypso Nicolaïdis, Richard G. Whitman, Emilian Kavalski, "The Struggle For Recognition of Normative Powers: Normative power Europe and normative power China in context," Cooperation and Conflict 48, no. 2 (2013): 247-67; Joe Tin-yau Lo and Suyan Pan, "Confucius Institutes and China's Soft Power: Practices and paradoxes," Compare: A Journal of Comparative and International Education 46, no. 4 (2016) 512-32; Xiaoling Zhang, Herman Wasserman, and Winston Mano, eds., China's Media and Soft Power in Africa: Promotion and Perceptions (New York: Palgrave Macmillan US, 2016), 195-203.
} 
the concept of "sovereign democracy," allow them to deliberately ignore human rights issues in order to achieve diplomatic advantage with respect to the US. ${ }^{27}$

I believe that linking status and soft-power research programmes would greatly benefit both disciplines. This connection could help assess the existence of a global standard of civilisation and its consequences. It could also shed light on possible ways in which rising powers try to challenge the existing normative order, if this is perceived as a constraint to their ability to achieve status, as well as on how old powers can or try to resist the rise of the new ones.

\section{Conclusion}

Status in World Politics constitutes an interesting, systematic, and necessary attempt to study status in IR. The authors share two background assumptions: First, despite a growing trend toward multipolarity, Euro-centrism or Western-centrism is still a problem afflicting IR theory, ${ }^{28}$ which is why the authors go beyond the usual focus on old powers and embrace an analysis of rising powers. Second, the growing importance of emotions in IR - such as shame, honour, and pride - are increasingly taken into account as independent or explanatory variables, ${ }^{29}$ and justifies the interest in a topic such as status that draws heavily on emotions.

Status in World Politics could be improved on two levels. First, it could give a more comprehensive definition of rising power, a concept central to the book's analysis. A broader definition would help shed light on how genuinely new powers have different status expectations compared to 'old' new powers, such as Russia. Second, the book would benefit greatly from an engagement with scholars of soft power, a concept that is more known and widely studied that status. A dialogue between the two research programmes is especially relevant in light of the current state of normative contestation of the Western liberal order, and in this sense opens up some interesting future research avenues, such as investigating possible ways in which rising powers challenge the existing normative order, if the latter is perceived as an obstacle in their status-seeking path.

The general view is that rising powers are critical of the post-World War II order and call for its reform, but at the same time there is no precise or shared idea about what a new order would look like. A recent report by the Paris-based EU Institute for Security Studies claims that “[p]rofound divergences between [rising powers'] political systems remain, and in many respects they are strategic competitors. In short, emerging powers lack a key ingredient of lasting cooperation: a common system of values or interests to bind them into a cohesive force." ${ }^{30}$ This statement is true to a certain extent, yet, we are currently witnessing changes brought about by a wave of conservative regimes in power globally today, comprised of re-emerging and current powers, that challenge the liberal values that have dominated since WWII. Regimes such as Putin's in Russia or Erdogan's in Turkey, the ascent of Trump in the US, the high vote (34\%) for Marine Le Pen in the recent French elections, and a general increase in the number and salience of far-right and Euro-sceptic parties and movements

\footnotetext{
${ }^{27}$ Chaka Ferguson, "The Strategic Use of Soft Balancing: The Normative Dimensions of the Chinese-Russian "Strategic Partnership," Journal of Strategic Studies 35, no. 2 (2012): 197-222.

28 Engin Sune, "Non-Western International Relations Theory and Ibn Khaldun," All Azimuth 5, no. 1 (2016): 79-88; Ali Karaomanoğlu and Ersel Aydınlı, "Introduction," All Azimuth 1, no. 1 (2012): 5-7.

29 Steve Shellman and Sean O'Brien, “An Empirical Assessment of the Role of Emotions and Behavior in Conflict Using Automatically Generated Data," All Azimuth 2, no. 2 (2013): 31.

30 "Strategy Matters 2015-2016," EU Key Documents (Paris: EU Institute for Security Studies, 2016), accessed March 20, 
in the EU make the question of normative contestation highly salient. Status researchers, especially if jointly collaborating with soft-power researchers, have the potential to address some relevant aspects of this complex and extremely topical question.

\section{Bibliography}

Bull, Hedley, and Adam Watson. The Expansion of International Society. Oxford: Oxford University Press, 1984. de Almeida, Paulo Roberto, and Diaz Miguel. "Brazil's Candidacy for Major Power Status." In Powers and Principles: International Leadership in a Shrinking World, edited by Michael Schiffer and David Shorr, 22556. Lanham, MD: Lexington, 2009.

Deng, Yong, and Fei-ling Wang. China Rising: Power and Motivation in Chinese Foreign Policy. Lanham: Rowman \& Littlefield, 2005.

Feklyunina, Valentina. "Soft Power And Identity: Russia, Ukraine and the "Russian world(s)." European Journal of International Relations 22, no. 4 (2015): 1-24.

Ferguson, Chaka. "The Strategic Use of Soft Balancing: The Normative Dimensions of the Chinese-Russian Strategic Partnership.” Journal of Strategic Studies 35, no. 2 (2012): 197-222.

Forsberg, Tuomas. "Status Conflicts between Russia and the West: Perceptions and Emotional Biases." Communist and Post-Communist Studies 47, no. 3 (2014): 323-31.

Freedman, Joshua. "Status Insecurity and Temporality In World Politics." European Journal of International Relations 22, no. 4 (2016): 797-822.

Gill, Bates, and Yanzhong Huang. "Sources and Limits of Chinese 'Soft Power'." Survival 48, no. 2 (2006): 17-36. Green, Michael. "Why we shouldn't judge a country by its GDP.” TED Ideas, Apr 22, 2015. Accessed April 10, 2017. http://ideas.ted.com/why-we-shouldnt-judge-a-country-by-its-gdp/.

Hill, Fiona. “Moscow Discovers Soft Power.” Current History 105 no. 693 (2006): 341-7.

Kahler, Miles. "Rising Powers and Global Governance: Negotiating Change in a Resilient Status Quo.” International Affairs 89, no. 3 (2013): 711-29.

Lo, Joe Tin-yau, and Suyan Pan. "Confucius Institutes and China's Soft Power: Practices and paradoxes." Compare: A Journal of Comparative and International Education 46, no. 4 (2016): 512-32.

Marlene Laurelle. “The Russian World.” International Affairs 55, no. 1 (2015): 116-22.

Nicolaïdis, Kalypso, Richard G. Whitman, and Emilian Kavalski. "The Struggle for Recognition of Normative Powers: Normative power Europe and normative power China in context." Cooperation and Conflict 48, no. 2 (2013): 247-67.

Nye, Joseph. The Future of Power. New York: Public Affairs, 2011.

Osipova, Yelena. "Russification of Soft Power: Transformation of a Concept." Exchange: The Journal of Public Diplomacy 5, no. 1 (2014): 56-77.

Paul, T.V., Deborah Welch Larson, and William C. Wohlforth, eds. Status in World Politics. New York: Cambridge University Press 2014.

Popescu, Nico. "Russia’s Soft Power Ambitions.” CEPS Policy Briefs 115 (2006): 1-3.

Stuenkel, Oliver. Post-Western World: How Emerging Powers Are Remaking Global Order. Cambridge: Polity Press 2016.

Tafuro Ambrosetti, E. "Building a Sphere of Influence in Their Neighbourhood: The Soft Power of Turkey and Russia.” PRIMO Working Papers Series 5, January 2017, Hamburg.

Zhang, Xiaoling, Herman Wasserman and Winston Mano, eds. China's Media and Soft Power in Africa: Promotion and Perceptions. New York: Palgrave Macmillan US, 2016. 
